\title{
Indicators of pleasure/pain in hygiene and cleaning outsourced workers of a university hospital*
}

\author{
Indicadores de prazer/sofrimento em trabalhadores terceirizados de higiene e limpeza de \\ um hospital universitário
}

Liana Bohrer Berni ${ }^{1}$, Carmem Lúcia Colomé Beck², Francine Cassol Prestes ${ }^{2}$, Rosângela Marion da Silva ${ }^{2}$, Susan Bublitz², Fabrício Lamb²

Objective: to measure the indicators of pleasure and suffering of hygiene and cleaning outsourced workers of a university hospital. Methods: a quantitative study of 51 workers at a university hospital in southern Brazil. A self-administered questionnaire with socio-occupational data and Pleasure Indicators Scale and Suffering at Work were used. There was descriptive and statistical analysis of the internal consistency of the factors using statistical program Predictive Analytics Software. Results: professional achievement and Freedom of expression, were evaluated respectively as satisfactory and critical pleasure indicators. Suffering indicator Lack of recognition was considered bearable and professional exhaustion as critical. Conclusion: the work context researched requires interventions that minimize the suffering of experiences, promote pleasure in work and, consequently, the health of contract workers hygiene and cleanliness.

Descriptors: Occupational Health; Outsourced Services; Housekeeping, Hospital.

Objetivo: mensurar os indicadores de prazer e de sofrimento dos trabalhadores terceirizados da higiene e limpeza de um hospital universitário. Métodos: estudo quantitativo, com 51 trabalhadores de um hospital universitário do Sul do Brasil. Utilizaram-se um questionário autopreenchível com dados sociolaborais e a Escala de Indicadores de Prazer e Sofrimento no Trabalho. Realizaram-se a análise estatística descritiva e de consistência interna dos fatores, por meio do programa estatístico Predictive Analytics Software. Resultados: realização profissional e Liberdade de expressão, indicadores de prazer, foram avaliados, respectivamente, como satisfatório e crítico. $\mathrm{O}$ indicador de sofrimento Falta de reconhecimento foi considerado suportável e o de Esgotamento profissional, como crítico. Conclusão: o contexto laboral pesquisado necessita de intervenções que minimizem as vivências de sofrimento, promovam o prazer no trabalho e, consequentemente, a saúde dos trabalhadores terceirizados da higiene e limpeza.

Descritores: Saúde do Trabalhador; Serviços Terceirizados; Serviço Hospitalar de Limpeza.

\footnotetext{
*Article extracted from the dissertation entitled "Prazer-sofrimento de trabalhadores terceirizados da higiene e limpeza de um hospital público", Universidade Federal de Santa Maria, 2013.

${ }^{1}$ Centro Universitário Franciscano. Santa Maria, RS, Brazil.

${ }^{2}$ Universidade Federal de Santa Maria. Santa Maria, RS, Brazil.

Corresponding author: Carmem Lúcia Colomé Beck

Av. Roraima, 1000. Prédio 26, sala 1304. Cidade Universitária, Bairro Camobi, CEP: 97105-900. Santa Maria, RS, Brazil. E-mail: carmembeck@ gmail.com
} 


\section{Introduction}

The work is part of the construction of the human being and, through the act of working; there is also the possibility of mediation between the unconscious and the social field. Thus, the construction work intermediate identity and composes the historicization of the subject ${ }^{(1)}$.

This research is based on the theoretical framework of psychodynamic of work, which seeks to analyze the dynamics of work contexts characterized by various forces, which can be visible or not, able to influence this context and produce health or illness. To achieve this goal, the theoretical framework addresses the dynamic relationships between the organization of work and the worker's subjective processes ${ }^{(2)}$.

In these relationships, the suffering inherent in the human being cannot be viewed only from a negative point of view, since often it is the reality transformer and this change allows the feeling of pleasure. Thus, suffering can produce health or worker illness ${ }^{(1)}$.

Healthy can be exemplified from the face of impositions and pressures at work. On the other hand, the disease occurs when there are flaws in the way of facing suffering, and the desire to production stands about the wishes of workers ${ }^{(2)}$.

The hospital environment is characterized as an unhealthy work environment due to the peculiarities of the activities performed, such as contact with patients awaiting diagnosis or with various diseases, including infectious conditions capable of transmission. Such characteristics may make workers vulnerable to illness related to work $^{(3)}$.

From this perspective, it is reaffirmed the need for the field of occupational health to adopt different approaches on the complexities of today's work environments that are shown under new management and entail risks for workers ${ }^{(4)}$. Although there is research on indicators of pleasure and suffering of technical professionals working in health services ${ }^{(5-6)}$, there is still a need for this type of analysis with other workers, such as operational professionals.
Doctors, nurses, nursing technicians, among others, are considered as technical professionals who underwent special training to perform a particular function in hospitals. Operating professionals in hospitals are the cleaning maids, porters, kitchen assistants, among others, which carry out activities that also have relevance in this environment, but do not necessarily have training or specific course to work on the place and function they play. Situations experienced by these workers in the performance of their functions can also translate into feelings of pleasure and suffering.

In this context, there is the outsourcing of services to operational workers, which has been increasingly common in business. A study of cleaning workers in a hospital is warning that outsourcing can favor the emergence of diseases related to labor activity since the precariousness trend of working conditions and inequality among employees provide humiliating conditions and disfavor the establishment of a decent work environment ${ }^{(7)}$.

Workers who carry out hospital cleaning activities play a key activity in health services ${ }^{(8)}$ and circulate all environments, including those considered most unhealthy, such as insulation, purges, and morgues $^{(7)}$. In these spaces, they are exposed to dealing with human excreta, interact with people seriously ill in the death and suffering process. Often, these workers may seem "invisible" in the spaces in which they operate, which leads to impaired recognition and thus the pleasure of experiences related to this work activity.

The study shows that the health and hospital cleaning service workers have an early entry into the labor market, low education, and low pay. Also, there are other features such as the need for muscular effort for lifting and carrying weight, performing repetitive movements, exposure to chemicals and the risk of accidents at work ${ }^{(9)}$. Even before a work context potentially unfavorable to the health of these workers, often the training and service education activities are insufficient to instrumentalize them in situations that 
can trigger suffering and illness.

In this context, it is mentioned that in many Brazilian hospitals, nursing service is responsible for the work of the management of cleaning and hygiene services, which justifies the relevance of studies on the health of workers who work in these services also for nursing ${ }^{(9)}$. Moreover, there is still little research on the health of workers in hygiene and cleaning services that work in hospitals ${ }^{(3,9)}$.

Given the above, this study aims to measure the indicators of pleasure and suffering of outsourced workers hygiene and cleaning of a university hospital. It is understood that these indicators may be relevant actors and health who performs these functions.

\section{Methods}

This is a quantitative, descriptive study with hygiene and cleaning outsourced workers that operated a university hospital in southern Brazil. This institution is a teaching hospital with more than 300 hospital beds, concerning health and high complexity for more than 45 municipalities.

In the data collection period, which took place from April to May 2012, the private company providing outsourced services had 530 workers working in the surveyed hospital. Of them, 124 were hygiene and cleaning workers.

Inclusion criteria in the study were: to have work experience in the outsourced company in hygiene and cleaning function of the hospital for six months and be literate. The criterion of the operating time is justified by the research instrument used addresses the experiences of pleasure and suffering in the last six months of work ${ }^{(2)}$. The workers who were on vacation or leave during the data collection period were excluded. Among the exclusions, 62 workers had operating time less than six months, seven were on leave for health treatment, two were illiterate, and a worker was on vacation.

The 52 workers who met the inclusion criteria were approached individually, in the workplace, informed about the objectives, and invited to participate. Through their agreement to participate, to depend on availability of time at that moment, participants were gathered in groups of on average five members and instructed on how to complete the data collection instrument. This strategy aimed to provide a private environment where participants feel protected about their identity, and could answer questions during working hours and with the presence of the researcher who could help in case of any questions. The filling time of the questionnaires was around 30 minutes. There was a refusal to participate in the study.

The 51 participants answered information regarding the socio-occupational data, with questions about age, gender, marital status, education, working time in the hospital and job satisfaction and pleasure Indicators Scale and Suffering at Work. This is one of four scales that make up the Inventory of Work and Illness Risk, a validated, self-administered, and public domain instrument in Brazil, which evaluates some dimensions of the interrelationship between work and the risk of disease $\mathrm{e}^{(2)}$.

The Pleasure Indicators Scale and Suffering at Work consist of four factors: two assessing the experiences of pleasure at work, and two assessing the suffering of experiences. Factors related to pleasure are: Freedom of expression and Professional Achievement; and the factors that evaluate the suffering at work are professional exhaustion and lack of recognition. The occurrence of the indicators of pleasure/pain in the last six months of work are evaluated, and the items are presented in Likert scale, with values ranging from zero to 6: $0=$ never, $1=$ once, $2=$ twice, 3 =three times, $4=$ four times, $5=$ five times, and $6=$ six or more times ${ }^{(2)}$.

Data analysis was carried out in the Predictive Analytics Software, version 18.0 for Windows. It was conducted a descriptive analysis of the variables so that the qualitative variables (socio-occupational) were described by absolute and relative frequencies while the quantitative had the normal distribution, 
the mean, and standard deviation.

In the analysis of Pleasure Indicators Scale and Suffering at Work, as instructed by the instrument authors ${ }^{(2)}$, to the factors that assess the pleasure Freedom of expression (item 1-8) and Professional Achievement (item 9-17) - the items are positive, and the specification, qualification and how often it is experienced were classified into three different levels, with individual standard deviations, as follows: above 4 = satisfactory; between 3.9 and $2.1=$ critical and below $2.0=$ severe.

For factors that evaluate the suffering at work - Burnout (item 18-24) and Lack of recognition (item 25-32), which have negative items, the analysis was performed at the following levels: above $4=$ severe; between 3.9 and 2.1 = critical; below $2.0=$ bearable. The evaluation of the reliability of the factors was carried out by estimating the internal consistency through Cronbach's alpha coefficient.

The study complied with the formal requirements contained in the national and international standards of regulatory research involving human beings.

\section{Results}

As for the characterization of the participants, there was a predominance of females $(88.0 \%, \mathrm{n}=45)$, married $(51.0 \%, \mathrm{n}=26)$, aged $36-50$ years old $(51.0 \%$, $\mathrm{n}=26$ ) and who have not completed elementary school $(47.0 \%, \mathrm{n}=24)$. As for the service in the same function and institution, $43.0 \%(\mathrm{n}=22)$ had up to two years of work.

Concerning factors related to experiences of pleasure, it became clear that freedom of expression was assessed as critical $(\mu=3.42, \quad \mathrm{SD}=1.24)$ and professional achievement was considered satisfactory $(\mu=4.60 ; \mathrm{SD}=1.18)$. The factors that evaluate the suffering related to labor activity, identified the Burnout syndrome with critical evaluation $(\mu=2.07$, $\mathrm{SD}=1.22$ ) and the lack of recognition was considered bearable $(\mu=1.08, \mathrm{SD}=1.01)$ (Table 1$)$.
Table 1 - Average score, standard deviation, evaluation and Cronbach alpha of factors related to pleasure and suffering experiences

\begin{tabular}{cccccc}
\hline Indicator & Factor & Average & $\begin{array}{c}\text { Standard } \\
\text { deviation }\end{array}$ & Evaluation & $\begin{array}{c}\text { Cronbach } \\
\text { Alpha }\end{array}$ \\
\hline & $\begin{array}{c}\text { Freedom of } \\
\text { expression }\end{array}$ & 3.42 & 1.24 & Critical & 0.72 \\
Pleasure & $\begin{array}{c}\text { Professional } \\
\text { achievement }\end{array}$ & 4.60 & 1.18 & Satisfactory & 0.88 \\
& $\begin{array}{c}\text { Professional } \\
\text { Burnout }\end{array}$ & 2.07 & 1.22 & Critical & 0.64 \\
\hline $\begin{array}{c}\text { Luck of } \\
\text { recognition }\end{array}$ & 1.08 & 1.01 & Bearable & 0.77 \\
\hline
\end{tabular}

The Freedom of expression factors and professional achievement (experiences of pleasure) and the factor Lack of recognition (suffering experience) had Cronbach alpha values above 0.70 . The professional Burnout factor (experience of suffering), had an alpha value of 0.64 .

In Table 2, two items with the most negative evaluations of each factor are shown.

Table 2 - Items with more negative assessment of each factor Indicators Scale and Suffering at Work

\begin{tabular}{lllll}
\hline Factor & \multicolumn{1}{c}{ Item } & Average & $\begin{array}{l}\text { Standard } \\
\text { deviation }\end{array}$ & Evaluation \\
\hline & $\begin{array}{l}\text { Confidence among } \\
\text { colleagues }\end{array}$ & 3.12 & 2.19 & Critical \\
$\begin{array}{l}\text { Freedom of expres- } \\
\text { sion }\end{array}$ & $\begin{array}{l}\text { Freedom with the } \\
\text { leadership to negoti- } \\
\text { ate what they need }\end{array}$ & 2.47 & 2.35 & Critical \\
& $\begin{array}{l}\text { Satisfaction } \\
\text { P r o f e s s i o n a l }\end{array}$ & 4.22 & 1.65 & Satisfactory \\
achievement & $\begin{array}{l}\text { Recognition } \\
\text { Emotional exhaustion }\end{array}$ & 2.86 & 2.24 & Critical \\
out & $\begin{array}{l}\text { Stress } \\
\text { Lack of recognition of } \\
\text { my effort }\end{array}$ & $1 ., 82$ & 2.01 & Bearable \\
Lack of recognition Burn- & Indignation & 1.67 & 2.00 & Bearable \\
\hline
\end{tabular}

The table identifies that the freedom of expression factor, confidence among colleagues and freedom with the leadership to negotiate what they need were both less frequent pleasure of experiences among participants. In this factor, the item solidarity among colleagues $(\mu=4.43, \mathrm{SD}=1.75)$ was only rated as 
satisfactory by the workers.

The second factor of pleasure, Professional achievement, all items were satisfactory evaluated. Pleasure, indicators with the lower averages satisfaction and recognition (Table 2). Items pride for what I do $(\mu=5.22, \mathrm{SD}=1.48)$ and identification with my duties $(\mu=5.06, S D=1.47)$ were the most frequent pleasure of experiences among participants.

In Professional Burnout factor, three from the seven items were considered satisfactory, and the others presented critical evaluation. The two items with more negative assessment were emotional exhaustion and stress.

On Lack of recognition factor, with bearable assessment in all items, the suffering experienced more negative assessed were a lack of recognition of the effort and indignation. The experience of suffering in this less frequent factor was the uselessness $(\mu=0.27, \mathrm{SD}=0.66)$.

\section{Discussion}

As research limitations, there was the number of workers because those who were excluded for not having the minimum operating time of six months. Similarly, it is mentioned the fact that it was held at a single university hospital. These aspects need to be reassessed in new research to enable further analysis or even compare the results already found.

The results indicate that the freedom of expression indicators (pleasure) and Burnout (suffering) need to be reviewed in the employment context investigated. Possible interventions are a lack of planning by the contractor company managers, with the creation of spaces where workers can express their feelings and needs about work activity, which may contribute positively to their health. Listening to the workers seems to be a fundamental condition for proposing measures that can minimize suffering by the lack of freedom of expression and burnout. These are also aspects to be considered by the nurse, as this often coordinates or participates in the management of hygiene and cleaning services.

This study encourages discussion on indicators of pleasure and suffering of workers who perform hygiene and cleaning activities in hospital services and highlights the importance of looking for a work environment that fosters the reframing of suffering and pleasure experiences, contributing to the health of workers.

Regarding the internal consistency of the factors evaluated, the results can be considered satisfactory, since values above 0.6 show that the internal consistency of the instrument is adequate ${ }^{(10)}$.

As for the characterization of the population surveyed in this study, there is convergence with the results of other surveys of employees who worked in the cleaning area in the hospital, in which there was a predominance of females and older than 30 years $\operatorname{old}^{(3,9,11)}$.

There is still the sexual division of labor and observed asymmetries and gender inequalities in the world of current jobs. In it, men occupy the most prestigious positions, qualifications, status and better pay to the detriment of women, although they represent a significant contingent, predominantly develop precarious activities with low wages, low social recognition and lower qualification requirements ${ }^{(12)}$.

Research on the ability to work with hygiene and cleaning workers of a university hospital cites the influence of gender in this occupation that can be explained by the fact that, culturally, the female figure to be linked to household chores like washing, cleaning and sweeping ${ }^{(13)}$.

The education of the participants in this study differs from research with outsourced cleaning workers at a university hospital in which most 
respondents had or was in high school ${ }^{(7)}$. The working time, as well as study of outsourced public cleaning agents $^{(14)}$ also identified a high turnover of workers in the service.

The study participants considered the first factor of pleasure, Freedom of expression, critical. The result is similar to that found in research with public cleaning agents acting on third party service provider of cleaning and maintenance services to a municipality in Northeast Brazil ${ }^{(14)}$, with nurses who work in intensive care units in a private hospital in the Southeast Region ${ }^{(6)}$ and nursing workers in a hemodialysis center in southern Brazil ${ }^{(15)}$.

Also, it was identified a consonance between the results of this study and the survey of public cleaning agents $^{(14)}$ regarding the assessment of the items that make up the factor. In both studies, the freedom with the leadership to negotiate what they need and lack of confidence among colleagues were the experiences of pleasure with the worst evaluation. This result differs from the assessment carried out by nurses working in units of the Family Health Strategy, in which these indicators were considered satisfactory ${ }^{(5)}$.

For the item lack of freedom with the board, it was recognized that, for a better organization of work, the desirable is that there is a space for worker cunning intelligence manifest. This means the fundamental curiosity of the subject, for them to seek a sense to do their jobs, to express their opinion and recognized by other $^{(1)}$.

The commitment to the experiences of pleasure at work by the lack of confidence among colleagues, as evidenced in this study is consistent with the results of a survey of the cleaning operations of the emergency unit, which identified the interpersonal relationships with colleagues constituted psychological burdens in that work context. Also, participants stressed the importance of teamwork as a strategy to make a pleasurable work ${ }^{(3)}$.
In this direction, as in this study, the item solidarity among colleagues was considered satisfactory and contributed positively to the pleasure of living in the work of nurses who work in intensive care units in a private hospital ${ }^{(6)}$ and the nursing staff who worked in a hemodialysis service ${ }^{(15)}$.

As the psychodynamics of work, the pleasure is also linked to the possibility of innovation, creation and development of new ways to perform tasks ${ }^{(2)}$. Thus, the way the cleaning is performed in a hospital, with established protocols for processes, may be associated with the critical evaluation of study participants regarding the lack of freedom of expression.

The second factor of pleasure, professional achievement, obtained satisfactory assessment similar to other studies ${ }^{(14-15)}$ and indicates a high degree of pleasure at work ${ }^{(2)}$. Thus, the evaluation of the participants of this research can be considered positive if compared to a study of technical professionals, which identified the items that contribute to feelings of pleasure, expressed through professional achievement, was at critical levels both for nurses and for nursing technicians ${ }^{(5)}$.

The professional performing experiences less frequent were the satisfaction and recognition, but also assessed as satisfactory. This result converges with the identified research with hospital service workers cleaning that most participants reported being often or always satisfied with daily activities ${ }^{(9)}$. In respect to recognition, the psychodynamics of work considers that although part of the expectations of all workers, hardly the recognition is conferred satisfactorily ${ }^{(1)}$.

Items of pride in what I do and the identification of tasks were the experiences of pleasure more positive assessment of the factor, which confirms the results of another survey of public cleaning agents ${ }^{(14)}$ and nursing staff ${ }^{(6,15)}$ where these experiences were also 
considered satisfactory. In the same sense, research carried out in Canada with cleaning workers who worked in pediatric and neonatal intensive care units found that participants had proud of the work they intend to do a good job and commitment to patients and families ${ }^{(8)}$.

The hospital cleaning job is crucial, since preparing the environment for the performance of activities by removing microorganisms and contributes to an adequate physical space for the performance of a warm, problem-solving and human care $^{(7)}$. The sense of pride in what I do, identified in this study, may refer to the understanding by the participants of the importance of their work has to the proper functioning of the hospital and, consequently, to the other people who work there and are assisted.

Despite the satisfactory assessment of the professional achievement factor, points to a possible contradiction between this assessment and the high turnover of workers identified during this study. Moreover, the turnover may compromise the experiences of pleasure at work among workers who remain active. In this sense, research conducted with professionals of the multidisciplinary health team who worked in inpatient oncology unit shows turnover as one of the dissatisfaction factors at work, mainly by unpreparedness of some professionals to carry out the activities in the area ${ }^{(16)}$.

The first factor that evaluates the suffering at work, lack of recognition, is evaluated by the frequency of experiences such as anger, injustice, devaluation and lack of recognition ${ }^{(2)}$. It was identified that this was not a common experience for the participants of this study (bearable assessment), a result that differs from the critical assessment by public cleaning agents $^{(14)}$.

Research with the cleaning agent of a unit of emergency department mentions the lack of recognition of the work as a present aspect in the employment context researched. The participants mentioned both the feeling of devaluation by the other professionals and by society, which demonstrates the existence of pre-concept in this occupation ${ }^{(3)}$.

This aspect was also mentioned in a study of outsourced cleaning workers at a university hospital. The results suggest that, among the interdisciplinary team, the nursing did not seem to consider these workers imposed constraint in the absence of adequate working conditions as if they do not compose the health team ${ }^{(7)}$.

Research on working conditions among nursing workers in a public hospital in Brazil showed the coexistence of different forms of contracting for the same function. Workers on temporary contracts, even if performing the same functions, they received less pay and had overhead the working day than those who had stable bonds. Also, the indirect link with the institution involved in feelings of embarrassment and hypo-confidence on workers on temporary contracts $^{(17)}$.

In the same way, a survey reports that there was an apparent disregard by the hospital with workers cleaning by being outsourced. When got sick and needed some immediate attention participants felt devalued, since the requirement that only service contractor, the hospital did not arise in the obligation to provide care to their health ${ }^{(7)}$.

It is noteworthy that to be valued by themselves and by the team are positive aspects of work and contribute to the maintenance of self-esteem and psycho-emotional balance of the employee. Thus, be recognized professionally for a job is important for motivation and improves the quality of life of workers $^{(3)}$.

Even getting the highest average in the factor, the feelings of lack of recognition of my effort and 
indignation were not frequent suffering of experiences among workers surveyed in this study. This result can be considered positive, since the recognition has a key role to workers' health because it sets the valuation process of the effort and suffering invested in performing the work ${ }^{(18)}$.

In this sense, recognition enables the construction of the identity of the subject, by assigning meaning to the committed effort to carry out the task that translates into experiences of pleasure and self-fulfillment ${ }^{(2)}$. For these reasons, despite the satisfactory evaluation factor, there is the need for this should constantly be evaluated, and to promote a work environment that fosters the professional recognition of experiences of workers.

The participants considered Professional Burnout as the second factor of suffering critical. This result is similar to that found in another study ${ }^{(14)}$ and expresses suffering of experiences and the possibility of illness related to labor activity.

A research infers that cleaning workers in hospitals are exposed to secretions, fluids, chemicals, proximity to patients with different health conditions, including the risk of imminent death ${ }^{(3)}$. The context described above may contribute to burnout of these workers, which refers to the critical evaluation factor by the participants of this study.

The feelings of emotional exhaustion and stress were the painful experiences with the worst evaluation factor, which converges with the results found with nursing workers in hemodialysis services ${ }^{(15)}$. This result may be related to the current configuration of activities in health services, which has demanded the intensification of work, which tends to reflect negatively on the health of workers ${ }^{(19)}$.

Hygiene and cleaning workers, while performing their routine work, interact and form relationships with patients. This is because, performing their activities, these workers are present in all hospital environments and in some situations contributing, even indirectly, in making the care of hospitalized patients ${ }^{(7)}$.

As mentioned, the bond with the patients may favor the experiences of pleasure before the attribution of meaning to the work and recognition of workers. However, it can translate into suffering through contact with disease situations, death and even impotence in the face of the health condition of some patients. Issues like these are described in research on the sources of satisfaction and dissatisfaction in the work of health professionals working in oncology ${ }^{(16)}$.

Thus, it is believed that the nature of work, the intensification of activities and contact with hospitalized patients may contribute to burnout of hospital cleaning workers, which refers to the critical evaluation factor attributed by the study participants.

For these reasons, it is confirmed that the experiences of pleasure/pain are dynamically articulated and are present in all workplace settings ${ }^{(18)}$. Similarly, it is reiterated that the hygiene and cleaning services workers in a hospital require specific and ongoing training to work in these scenarios, including emotional preparation for the development of activities in that environment, in many situations, it is permeated for pain and suffering.

In this regard, it is reaffirmed the need for the existence of working conditions that foster satisfaction and motivation of workers. Thus, a humanized working environment can be established and, consequently, better quality of care provided to patients $^{(17) .}$

\section{Conclusion}

Hygiene and cleaning outsourced workers of the researched hospital are evaluated the indicator pleasure professional achievement as satisfactory. Freedom of expression was considered critical, that is, there is a commitment to the experiences of pleasure evaluated this factor that may signal a moderate risk 
of disease in the study population.

As for suffering indicators, the lack of recognition was considered bearable, that is, these experiences are not common in the employment context researched. Professional Burnout factor was considered critical, which refers to a borderline assessment and requires interventions to prevent possible harm to the health of workers.

\section{Collaborations}

Bernie LB and Beck CLC contributed to the conception and design and analysis and interpretation of data. Prestes FC, Silva RM, Bublitz S and Lamb F contributed to the writing of the article, relevant critical review of the intellectual content and final approval of the version to be published.

\section{References}

1. Dejours C, Abdoucheli E, Jayet C. Psicodinâmica do trabalho: contribuições da Escola Dejouriana à análise da relação prazer, sofrimento e trabalho. São Paulo: Atlas; 2014.

2. Mendes AM. Psicodinâmica do trabalho: teoria, método e pesquisas. São Paulo: Casa do Psicólogo; 2007.

3. Martins JT, Ribeiro RP, Bobroff MCC, Marziale MHP, Robazzi MLCC, Mendes AC. Meaning of workload on the view of cleaning professionals. Acta Paul Enferm. 2013; 26(1):63-70.

4. Campos JF, David HSL. Work context assessment in intensive therapy units from the perspective of work psychodynamics. Rev Esc Enferm USP. 2011; 45(2):363-8.

5. Shimizu HE, Carvalho Júnior, DA. O processo de trabalho na Estratégia Saúde da Família e suas repercussões no processo saúde-doença. Ciênc Saúde Coletiva. 2012; 17(9):2405-14.
6. Campos JF, David HMSL, Souza NVDO. Pleasure and suffering: assessment of intensivist nurses in the perspective of work psychodynamics. Esc Anna Nery. 2014; 18(1):90-5.

7. Petean E, Costa ALRC, Ribeiro, RLR. Repercussões da ambiência hospitalar na perspectiva dos trabalhadores de limpeza. Trab Educ Saúde. 2014; 12(3):615-35.

8. Matlow AG, Wray R, Richardson SE. Attitudes and beliefs, not just knowledge, influence the effectiveness of environmental cleaning by environmental service workers. Am J Infect Control. 2012; 40(3):260-2.

9. Beltrame MT, Magnago TSBS, Kirchhof ALC, Marconato CS, Morais BX. Work ability in hospital housekeeping services and associated factors. Rev Gaúcha Enferm. 2014; 35(4):49-57.

10. Malhotra NK. Pesquisa de marketing: uma orientação aplicada. Porto Alegre: Bookman; 2001.

11. Cruz EDA, Pimenta FC, Hayashida M, Eidt M, Gir E. Staphylococcus aureus detection in the mouth of house keepers. Rev Latino-Am Enfermagem. 2011; 19(1):90-6.

12. Guiraldelli R. Adeus à divisão sexual do trabalho?: desigualdade de gênero na cadeia produtiva da confecção. Soc Estado. 2012; 27(3):709-32.

13. Silva LG, Haddad MCL, Domansky RC, Vituri DW. Capacidade para o trabalho entre trabalhadores de higiene e limpeza de um hospital universitário público. Rev Eletr Enf [periódico na Internet]. 2010 [citado 2015 Jul 28];12(1):158-63. Disponível em: https://www.fen.ufg.br/revista/v12/n1/pdf/ v12n1a19.pdf

14. Gomes CC, Oliveira RS. Agentes de limpeza pública: um estudo sobre a relação prazer/ sofrimento no ambiente laboral. Psicol Ciênc Prof. 2013; 33(n. spec.):138-53.

15. Prestes FC, Beck CLC, Magnago TSBS, Silva RM. Pleasure-suffering indicators of nursing work in a hemodialysis nursing service. Rev Esc Enferm USP. 2015; 49(3):465-72. 
16. Bordignon M, Ferraz L, Beck CLC, Amestoy SC, Trindade LL. (Dis)satisfaction of health professionals who work with oncology. Rev Rene. 2015; 16(3):398-406.

17. Ribeiro AC, Souza JF, Silva JL. Lack of employment security in the SUS in the perspective of hospital nursing. Cogitare Enferm. 2014; 19(3):524-30.
18. Dejours C. A loucura do trabalho: estudo de psicopatologia do trabalho. São Paulo: CortezOboré; 2009.

19. Dal Pai D, Krug JS, Lautet L. Psicodinâmica e saúde mental do trabalhador de enfermagem: ritmo acelerado e intensificação do prazer. Enferm Foco. 2011; 2(1):38-43. 